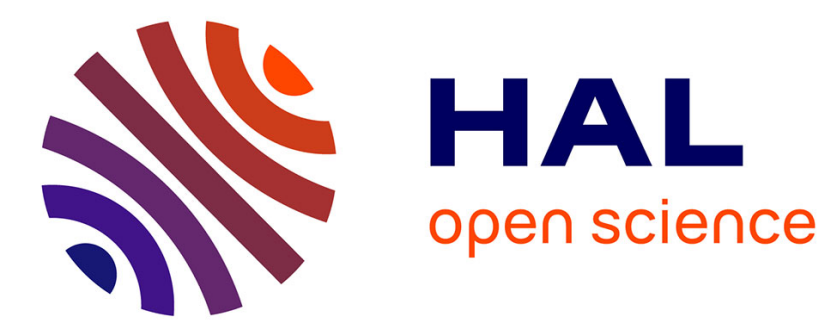

\title{
Temperant portfolio choice and background risk: evidence from France
}

Luc Arrondel, Hector Calvo Pardo, Xisco Oliver

\section{To cite this version:}

Luc Arrondel, Hector Calvo Pardo, Xisco Oliver. Temperant portfolio choice and background risk: evidence from France. 2007. halshs-00588069

\section{HAL Id: halshs-00588069 \\ https://shs.hal.science/halshs-00588069}

Preprint submitted on 22 Apr 2011

HAL is a multi-disciplinary open access archive for the deposit and dissemination of scientific research documents, whether they are published or not. The documents may come from teaching and research institutions in France or abroad, or from public or private research centers.
L'archive ouverte pluridisciplinaire HAL, est destinée au dépôt et à la diffusion de documents scientifiques de niveau recherche, publiés ou non, émanant des établissements d'enseignement et de recherche français ou étrangers, des laboratoires publics ou privés. 


\section{PARIS SCHOOL OF ECONOMICS}

WORKING PAPER N² 2007 - 16

Temperant portfolio choice and background

risk: evidence from France

Luc Arrondel

Hector Calvo Pardo

Xisco Oliver

JEL Codes: C33, C35, D12, D91

Keywords: portfolio choice, background risk, risk aversion, prudence, temperance 


\title{
Temperant Portfolio Choice and Background Risk: Evidence from France*
}

\author{
Luc Arrondel $\}^{\dagger}$ Hector Calvo Pardo ${ }^{\ddagger}$ and Xisco Oliver ${ }^{\S}$
}

June 6, 2007

\begin{abstract}
We explore empirically whether earnings uncertainty and borrowing constraints deter households from the stockmarket, consistent with the predictions of theoretical studies of portfolio choice in the presence of uninsurable earnings. Recent extensions highlight the importance of the correlation between earnings and financial risks. We use a selfassessed proxy for the correlation from the DELTA-TNS 2002 crosssectional survey. While income risk does not deter from the stockmarket those households' reporting a negative correlation, it does for those who report a non-negative sign, consistent with economic theory predictions.
\end{abstract}

${ }^{*}$ The authors specially thank the Editor, three anonymous referees, Rob Alessie, Louis Eeckhoudt, Carl Emmerson, Michael Haliassos, Andre Masson, Muriel Roger, Jean-Marc Robin, Pamela Spadaro, Christian Schluter, Jackie Wahba and comments from seminar participants at the Bank of Spain, RTN-AGE group (Copenhague, London), ESEM 2003 (Stockholm), FGV (Rio de Janeiro), Jamboree Meeting LSE (London), PSE lunch seminar and Southampton lunch seminar. We acknowledge research support from CNRS and SEEUID. The second author acknowledges financial support from the Bank of Spain. Xisco Oliver also acknowledges financial support from the Spanish Government-MYCT (Programa nacional de promocion general de conocimiento SEJ2005-08783-C04-03/econ) and from the EU RTN, under contract HPRN-CT-2002-00235 (AGE).

${ }^{\dagger}$ CNRS-PSE (Joint Research Unit of CNRS-EHESS-ENPC-ENS)-FEDEA. Postal address: ENS Bat. A, 48 Bd. Jourdan, 75014 Paris. France. Corresponding author: arrondel@pse.ens.fr.

$\ddagger$ University of Southampton.

$\S$ Universitat de les Illes Balears. 


\section{Introduction}

The main challenge incorporating background risks is to specify a realistic model for the joint distribution of these risks with asset returns... Michael Brandt (2004).

There has been growing interest on the implications of incomplete markets for both theoretical and empirical reasons. Perhaphs among the most important ones are the puzzles identified in the economics and finance literatures when confronting theoretical predictions with real data ('equity premium', 'nonparticipation', 'home bias'...). Recent availability of household-level data sets is guiding new theoretical developments and shaping the understanding of older ones, since new puzzles are emerging (Guiso et al. $(2002,2003)$ ).

The classical theory of portfolio choice was developed in a complete markets framework, meaning that all individual risks could be traded. It identified, as determinants of households' demand for stocks, the expected excess return of stocks over riskless assets, the objective risk of stocks as measured by its variance, and households subjective perception of that risk as measured by their risk aversion. The observation that severe informational restrictions precluded most households from insuring their labor earnings, and yet, was their most important source of lifetime income, motivated the reconsideration of the complete markets assumption. This reconsideration led to important departures from the predictions of the classical theory. Drèze and Modigliani $(1966,1972)$ already observed that an important consequence of the non-insurability of earnings risks was that portfolio and labor market decisions become connected. Intertemporal extensions to incorporate nontradable and undiversifiable income (Koo (1999), Davis and Willen (2000) or Viceira (2001) among many others), borrowing and liquidity constraints (Koo (1999), Haliassos and Michaelides (2003)), indivisibilities like housing (Brueckner (1997), Flavin and Yamashita (2002)), age (Gollier and Zeckhauser (1997), Viceira (2001) or Campbell and Viceira (2002)), or information and transactions costs (King and Leape (1987), Vissing-Jorgensen (2002) or Haliassos and Michaelides (2003)), have also been pervasively studied empirically thanks to the increased availability of household-level data. In this work we use household-level survey data to examine these theoretical developments on a sample of French households.

One of the most recent theoretical extensions of the classical portfolio choice model has formalized the following common wisdom intuition: when risk averse households are confronted with a risk beyond their control - 
exogenous or 'background' risk (hereafter)-, they should be willing to decrease their exposure to other avoidable risks -endogenous risks- in order to adjust their desired total risk exposure (Pratt and Zeckhauser (1987), Kimball (1993), or Gollier and Pratt (1996)). Households observing this behaviour are called 'temperant'. Accordingly, and as labor income is uninsurable, those 'temperant' households who suffer more from labor market uncertainty should choose to be less exposed to financial risk, ceteris paribus. As well, changes in the income risk that increase households exposure to unavoidable risks should compel them to crowd out from the stock market ${ }^{2}$. Although there is empirical evidence supporting this theoretical prediction using household-level data (Guiso et al. (1996) for Italy, Massa and Simonov (2006) for Sweden or Haliassos and Bertaut (1995) and Vissing-Jorgensen (2002) for the US), other empirical studies have not been able to confirm it (Hochguertel (1998) or Alessie et al. (2002) for The Netherlands, Arrondel and Masson (1996) or Arrondel and Calvo (2002) for France).

More recently, surprising empirical results about the correlation between earnings and financial risks have been known. Davis and Willen (2000) or Heaton and Lucas (2000) show that, contrary to educated intuition received from equilibrium economic models, both risks tend to be independent in the aggregate and differently correlated depending on the income decomposition criterion chosen. Vissing-Jorgensen (2002) for the US or Massa and Simonov (2006) for Sweden, provide empirical evidence on the absence of a significant impact of the correlation on households' demand for risky assets using individual longitudinal datasets. Yet, both the standard theory of portfolio choice and empirical works emphasize the importance of the correlation component, e.g. in addressing the home-bias puzzle (Botazzi et al. (1996), Palacios-Huerta (2001) or Julliard (2004)). Confronted with such ambiguity, we follow Dominitz (1998, 2001), Dominitz and Manski (1997) or Manski (2003) and propose individually self-assessed measures that proxy both the correlation and earnings uncertainty exploiting French household survey data (DELTA - TNS 2002). Earnings risk is found to have a negative impact on households' decision to hold risky assets provided that we control for the correlation, in line both with the results obtained for other countries

\footnotetext{
${ }^{1}$ Strictly speaking, Eeckhoudt and Schlesinger (2006) show that 'temperance' is a household's preference property characterizing her optimal choices in a class of lotteries (zeromean independent lotteries). We are going to use it in a more general sense.

${ }^{2} \mathrm{~A}$ synthesis of the empirical studies documenting the rise in labor market uncertainty for most OECD countries can be found in Katz and Autor (1999).
} 
and theoretical predictions.

The rest of the work proceeds as follows. In section 2 we summarize the theoretical assumptions and empirical implications underlying the adverse impact of correlated undiversifiable earnings on financial risk taking (temperant stockholding behaviour). In section 3, we describe the 'DELTA - TNS 2002' household survey and assess empirically the theoretical predictions on households' decisions to invest in stocks. Section 4 concludes.

\section{Temperant Stockholdings with a Correlated Background Risk}

Drèze and Modigliani's $(1966,1972)$ pioneering work has lead researchers to reconsider the classical theory of portfolio choice, originally developed by Arrow (1965) under the assumption that all individual income risks can be traded (complete markets). In this section we only consider the theoretical implications of removing the assumption of complete markets for the standard static portfolio choice problem ${ }^{3}$.

Under complete markets, the problem a household faces is how to invest her current wealth $w_{0}$ when there are only two assets available: a risky asset promising to deliver tomorrow a random return $\widetilde{r}$ and a riskless asset promising the delivery of a sure return $r$. Her individual objective function is a continuous differentiable representation of his preferences that admit an expected utility form over final wealth $w_{f}$. Denoting by $\alpha$ the amount of initial wealth that is invested in the risky asset, by $\widetilde{z} \equiv \widetilde{r}-r$ the excess return of the risky asset over the riskless asset, and by $w \equiv w_{0}(1+r)$ the final wealth had she invested all her current wealth $w_{0}$ in the riskless asset, we can write the solution $\alpha^{*}$ to her individual optimization problem under the small risk approximation as:

$$
\alpha^{*} \simeq \frac{E \widetilde{z}}{\sigma_{z}^{2} A_{u}(w)} \in \arg \max _{\alpha} E u(w+\alpha \widetilde{z})
$$

Where $A_{u}(w) \equiv-\frac{u^{\prime \prime}(w)}{u^{\prime}(w)}$ is the standard Arrow-Pratt coefficient of absolute risk aversion evaluated at the agents' wealth $w$ when the agent's preferences are represented by utility $u($.$) .$

\footnotetext{
${ }^{3}$ To consider the effect of liquidity constraints or investor horizons is beyond the scope of this short section, and is relegated to the discussion of empirical results. A good textbook treatment is Gollier (2001).
} 
Now, assume that the household cannot trade her labor income risk $\widetilde{y}$ (incomplete markets). Will she invest more in risky asssets? Under the small risk approximation, optimal stockholdings become:

$$
\widehat{\alpha} \simeq \frac{E \widetilde{z}}{\sigma_{z}^{2} A_{v}(w)} \in \arg \max _{\alpha} E u(w+\alpha \widetilde{z}+\widetilde{y})
$$

Where now $A_{v}(w) \equiv-\frac{v^{\prime \prime}(w)}{v^{\prime}(w)}$ and $v(t) \equiv E_{y} u(t+\widetilde{y})$ is the indirect utility function, as defined by Kihlstrom et al. (1981). Common wisdom would suggest that increasing household's exposure to risks beyond her control should lead her to decrease her optimal exposure to risks under her control, i.e. risks are substitutes rather than complements. Formally, Pratt and Zeckhauser (1987), Kimball (1993) or Gollier and Pratt (1996) showed that substitution between risks means conditions under which the change in preferences from $u($.$) to v($.$) leads households to be more risk averse in the presence of the$ independent background risk on income $\widetilde{y}$ :

$$
A_{v}(w) \geq A_{u}(w) \Longrightarrow \widehat{\alpha} \leq \alpha^{*}
$$

Using a cross-section of Italian households (SHIW), Guiso et al. (1996) were the first to provide empirical validity for this comparative statics property. Vissing-Jorgensen (2002) and Heaton and Lucas (2000) also find evidence that background risk reduces stock market participation in the United States, as do Massa and Simonov (2006) for Swedish households. Hochguertel (1998) results for the Netherlands are inconclusive and those of Alessie et al. (2001) for the same country did not find a significant effect of income uncertainty on the demand for risky assets. Arrondel and Masson (1996, 2003) or Arrondel and Calvo (2002) obtain a different result for France: as households are more exposed to earnings risk (proxied by occupation sectors), they tend to own more stocks. Rather than dismissing the theoretical prediction, a natural assumption to relax is the hypothesis that household income $\widetilde{y}$ and stock market excess returns $\widetilde{z}$ are independent.

Specializing to the assumptions ${ }^{4}$ of Kimball (1993), Arrondel and Calvo (2002) extend the results of this literature to dependent background risks

\footnotetext{
${ }^{4}$ Kimball (1993) shows that condition [3] holds if and only if utility exhibits standard risk aversion whenever household income risk is loss-aggravating. Utility exhibits standard risk aversion whenever it displays decreasing absolute risk aversion (DARA) and decreasing absolute prudence (DAP). A risk $\widetilde{y}$ is loss-aggravating when starting from initial wealth $w$ if and only if $E u^{\prime}(w+\widetilde{y}) \geq u^{\prime}(w)$. Observe that this is equivalent to $E \widetilde{y} \leq \Psi: \Psi$ is the
} 
of the form introduced by Elmendorf and Kimball (2000). Following the latter, define now income risk as $\widetilde{y}_{c}=\widetilde{h}+\beta \widetilde{z}$ where subindex 'c' accounts for 'correlated', since the parameter $\beta$ captures a non-zero correlation between $\widetilde{y}_{c}$ and $\widetilde{z}$. Then, under the small risk approximation the household's risky asset demand is given by:

$$
\bar{\alpha} \simeq \frac{E \widetilde{z}}{\sigma_{z}^{2} A_{\widehat{v}}(w)}-\beta \in \arg \max _{\alpha} E u\left[w+\alpha \widetilde{z}+\widetilde{y}_{c}\right]
$$

We can then define total stockholdings $\theta$ as the sum of two components: a fixed implicit component given by the correlation $\beta$, and a variable explicit component $\bar{\alpha}$ directly managed by the household so as to adjust total stockholdings to its optimal value $\widehat{\theta} \equiv \bar{\alpha}+\beta \simeq \frac{E \widetilde{z}}{\sigma_{z}^{2} A_{\widehat{v}}(w)}\left({ }^{5}\right)$. We can then express the analogue of property (3), that will be the object of empirical scrutiny in section $3, \mathrm{as}^{6}$ :

$$
A_{\widehat{v}}(w) \geq A_{u}(w) \Longrightarrow \bar{\alpha}+\beta \equiv \widehat{\theta} \leq \alpha^{*}
$$

CRRA Example: Specifying the utility function to be $u(w)=\frac{w^{1-\gamma}}{1-\gamma}$ : $\gamma \equiv w A_{u}(w)$, and assuming that rate of return risk and earnings are jointly lognormally distributed, the (approximation) technique presented in Campbell and Viceira (2002) yields the following decomposition of the weak inequality in the right hand side of (5):

$$
\begin{aligned}
\widehat{\theta}-\alpha^{*} & =\frac{1}{\epsilon}\left(\frac{E \widetilde{z}}{\sigma_{z}^{2} \gamma}-\beta\right)-\frac{E \widetilde{z}}{\sigma_{z}^{2} \gamma} \\
& =\underbrace{\left(\frac{1}{\epsilon}-\frac{1}{\epsilon_{c}}\right) \frac{E \widetilde{z}}{\sigma_{z}^{2} \gamma}}_{(-) \text {Risk Substitution Effect }}+\underbrace{\left(\frac{1}{\epsilon_{c}}-1\right) \frac{E \widetilde{z}}{\sigma_{z}^{2} \gamma}}_{(+) \text {Income Effect }}-\underbrace{\frac{1}{\epsilon} \beta \leq 0}_{\begin{array}{c}
\text { Hedging Effect: } \\
(+) \text { if } \beta>0 ;(-) \text { if } \beta<0
\end{array}}
\end{aligned}
$$

precautionary premium as defined by Kimball (1990). In intuitive terms, they are risks that make the agent willing to pay a bigger amount than its expected value in order to keep as optimal the decision prevailing before the risk was introduced. Finally observe that if preferences are DARA, every undesirable risk is loss-aggravating.

${ }^{5}$ In a CAPM framework, Davis and Willen (2000) termed them, respectively, by 'endowed' (Hedging component), 'desired' (Markowitz component) and 'total' exposures to rate of return risk. Here we follow the terminology of Elmendorf and Kimball (2000).

${ }^{6}$ Because the independent component of the background risk $\widetilde{h}$ has a negative impact on total stockholdings if and only if it is in the loss-aggravating class of risks and households' preferences are standard (DAP and DARA). Therefore $\widehat{\theta} \leq \alpha^{*}$. 
where $\frac{1}{\epsilon}=1+\frac{E \widetilde{y} \exp \left\{-\frac{1}{2} \sigma_{y}^{2}\right\}}{\exp \left\{E \widetilde{r}+w_{0}\right\}}>\frac{1}{\epsilon_{c}}=1+\frac{E \widetilde{y}}{\exp \left\{E \widetilde{r}+w_{0}\right\}} \cdot \frac{1}{\epsilon}\left(\frac{1}{\epsilon_{c}}\right)$ is the inverse elasticity of total wealth with respect to financial wealth when labour income is stochactic and (non-stochastic but) non-tradable. When non-stochastic, it is equal to the expected value of uncertain earnings $\widetilde{y}_{c}$.

The equality from (6) to (7) follows from adding and subtracting the optimal portfolio $\frac{1}{\epsilon_{c}} \frac{E \widetilde{z}}{\sigma_{z}^{2} \gamma}$ of a household with certain but nontradable labour income $y=E \widetilde{y}_{c}$. The first additive term in (7) captures the negative effect on the complete markets optimal portfolio $\alpha^{*}$ of introducing an independent zero-mean background risk $\widetilde{y}-y: E \widetilde{y}=E \widetilde{y}_{c}$ (risk-vulnerable reaction, in Gollier and Pratt's (1996) terminology). The second term in (7) captures the positive effect on $\alpha^{*}$ of introducing an independent background risk with positive mean $E \widetilde{y}=y>0$, i.e. because preferences display decreasing absolute risk aversion, richer households are more willing to invest in stocks. The last term in (7) captures the 'hedging effect' to the extent that we allow for correlated earnings $\widetilde{y}_{c}$. Notice that it is interacted with the inverse elasticity $\frac{1}{\epsilon}$, which is itself a function of earnings variance $\sigma_{y}^{2}$, because for those households whose income risk is small, the hedging component will be negligible ${ }^{7}$.

Remark 1: (Empirical Implication) Recalling that we observe explicit asset holdings $\bar{\alpha}$ and not total asset holdings $\widehat{\theta}$, expression (5) shows that any empirical attempt to validate it requires a measure for the correlation $\beta$. For example, establishing empirically that $\alpha^{*} \geq \bar{\alpha}$ does not imply that households invest less in risky assets because they cannot trade their earnings risk (risk substitution effect). Households may explicitely hold less risky assets just because they are already implicitely investing in the stock market through their earnings, i.e. $\beta>0$ (Hedging effect). Conversely, suppose that we empirically detect that $\alpha^{*} \leq \bar{\alpha}$, concluding that the average (e.g. French) household invests more in risky assets the more exposed she is to earnings risk. This is only true provided that $\beta=0$. If on average $\beta<0$, it may actually be the case that $\widehat{\theta}=\bar{\alpha}+\beta \leq \alpha^{*}$ in line with what risk substitution prescribes when income risk is correlated, i.e. $(5) .\left({ }^{8}\right)$

\footnotetext{
${ }^{7}$ We thank an anonymous referee for pointing out this observation.

${ }^{8}$ Notice that assuming CARA preferences precludes any impact of introducing a correlated background risk beyond the hedging component, because then risk aversion is independent of wealth, i.e. $A_{\widehat{v}}(w)=A_{u}(w)$. This is also the case when mean-variance preferences are used as long as the income risk is non-tradable, for general joint statistical distributions of financial and labour returns.
} 
Remark 2: (Effect on Participation) Arrow (1965) established that under complete markets, if the expected excess return of investing in risky assets is positive, every risk averse household whose preferences can be represented by a differentiable felicity function should invest a fraction of her wealth in risky assets. Haliassos and Bertaut (1995) noticed that this theoretical prediction lacked empirical support using the 1983 US Survey of Consumer Finances, and called it the stockholding puzzle. Under incomplete markets however, if income risk is negatively correlated and non-diversifiable, rational risk averse households may optimally invest in the risky asset even if the expected excess return $E \widetilde{z}$ is negative, since it provides partial insurance against the exogenous earnings risk. And conversely: even if the stock market delivers a considerable positive risk premium, households whose incomes covariate positively with the stock market will optimally choose not to hold stocks if participation increases their global risk exposure beyond wish ${ }^{9}$. To the extent that at the individual level this correlation changes with the educational level and sector of activity (Davis and Willen, 2000), professional status and asset ownership (Heaton and Lucas, 2000), or stockownership status (Palacios-Huerta, 2001), this is likely to generate cross sectional variation in participation.

Remark 3: (Risk aversion as a determinant of the participation equation) If transaction costs are present (ex. sign-up or brokerage fixed fees), differences in risk aversion will also determine the decision to participate if households become less risk averse as their wealth or income increases (Haliassos and Bertaut (1995), Haliassos (2003), Haliassos and Michaelides (2003)). Further, conditioning on income and wealth, households with riskier incomes are also less prone to pay the fee for investing in risky assets.

\footnotetext{
${ }^{9}$ If we define the value function of the household evaluated at her optimal choice $\bar{\alpha}$ as $W(\bar{\alpha})=E u\left(w+\bar{\alpha} \widetilde{z}+\widetilde{y}_{c}\right)$, notice that $\left.W^{\prime}(\bar{\alpha})\right|_{\bar{\alpha}=0} \geq 0$ and thus $\bar{\alpha} \geq 0$ whenever $\operatorname{cov}\left[\widetilde{z}, u^{\prime}\right]>0$ even if $E \widetilde{z}<0$ (negative risk premium):

$$
\left.\operatorname{sign} W^{\prime}(\bar{\alpha})\right|_{\bar{\alpha}=0}=\operatorname{sign}\left\{E \widetilde{z}+\frac{\operatorname{cov}\left[\widetilde{z}, u^{\prime}\right]}{E u^{\prime}}\right\}>0
$$

Since $u^{\prime \prime}()<$.0 , the term $\operatorname{cov}\left[\widetilde{z}, u^{\prime}\right]>0$ is equivalent to $\operatorname{cov}\left[\widetilde{z}, \widetilde{y}_{c}\right]<0$ by Gollier's $(2001)$ proposition 15. And conversely.
} 


\section{Empirical evidence}

Guiso et al. (1996) provided empirical support to the adverse impact of unavoidable income risk and anticipated liquidity constraints on household stockholding decisions using Italian data ${ }^{10}$. Using their same specification and similarly constructed relevant variables, we confirm their findings on French household data if we control for the correlation between earnings and financial returns. When we exclude the correlation variable, income risk has no effect on the decision to invest in risky assets, at odds with theoretical predictions.

\subsection{Data description and risk variables}

We rely on the 'Mode de vie et épargne' household survey conducted by DELTA and Taylor Nelson-Sofres in 2002 (DELTA - TNS 2002) on a sample of 4000 French households with individuals between 35 and 55 years old, representative of the French population in the age bracket. Only 2518 households answered, of which 2460 could be exploited. This survey contains information on earnings, income, wealth, socio-economic status and demographic characteristics of the household. Questions that capture the degree of individual exposure and aversion to risk include those proposed by Barsky et al. (1997), based on relative risk-aversion to lotteries on lifetime labour income, and by Guiso and Paiella (2001, 2004), based on the degree of absolute risk-aversion to financial lotteries ${ }^{11}$. Finally, a question to proxy for the correlation between earnings and financial risk as subjectively perceived by individuals is for the first time available.

The DELTA-TNS 2002 survey contains qualitative information on the distribution of household financial assets in ten categories: cash, transactions and savings accounts, homeownership savings accounts, bonds (Treasury bills, certificates, fixed-rate long term bonds and other government paper), stocks from privatized public companies, private companies listed stocks, stocks of foreign firms, mutual funds and managed investment accounts, annuities, life insurance contracts and contributions to complementary pension plans. Table 1 reports the proportion of households holding each asset.

(Table 1 here)

\footnotetext{
${ }^{10}$ Empirical evidence for other European countries using a homogeneous methodology are collected in Guiso et al. (2003).

${ }^{11}$ See the appendix for details concerning both.
} 
We define direct stockholdings as the sum of stocks of privatised public companies, private companies listed stocks and stocks of foreign firms held, and as indirect stockholdings, those held through mutual funds and managed investment accounts. Although in some countries bonds have a considerable risk of default justifying their inclusion in the risky asset holdings (i.e. Guiso et al., 1996), this is not the case of France and we therefore exclude them. As well, we exclude homeownership from the risky asset category despite of being highly illiquid and indivisible (and therefore risky), because French households mostly buy houses for the flow of services it provides rather than as a financial investment (Arrondel, 1996). Still, in the estimation we control for the level of total net worth (real plus financial) and include a dummy variable that takes value one when houseownership status is observed. The proportion of households who hold stocks directly is $21 \%$, and $33 \%$ either directly or indirectly. Although low, the participation rates are similar to those obtained from previous INSEE surveys ${ }^{12}$ and to the figures from other European countries studied in Guiso et al. (2003) $\left({ }^{13}\right)$. The extent to which such low participation rates in financial risk are explained by both earnings risk and the expectation of being liquidity constrained is subject to empirical scrutiny.

Available data to capture earnings uncertainty is scarce, as we show below. Therefore we construct a proxy for the subjective income variance as follows: we estimate it conditional on a vector of characteristics from the wealth INSEE survey 'Patrimoine 98', and predict earnings uncertainty for DELTA-TNS 2002 households. Since each labor income recipient in 1998 was asked to attribute probability weights to given intervals of real income increases five years ahead, we can match 1998 and 2002 data $^{14}$. In the Appen-

\footnotetext{
${ }^{12}$ The figures are comparable with those of the 'Patrimoine 1998' household survey conducted by the French National Institute for Statistics and Economic Studies (INSEE). For the 35-55 year-olds corresponding subsample, the proportion of households holding risky assets 'directly' is 21.6 and either directly or through mutual funds, 32.4. Arrondel and Masson (2003) provide a thorough description of household portfolios using the 'Patrimoine 98' INSEE household survey.

${ }^{13}$ The increased participation relative to previous studies using French data is due to the restricted age bracket sampled (i.e. between 35 and 55 year-old individuals are more likely to participate), and not to a real increase in participation as shown in Arrondel (2003).

${ }^{14}$ Assuming that five years ahead expected real income is $y_{t+5}=y_{t}(1+\bar{x})$, then the formula of the expected variance of household income is $\operatorname{var}\left(y_{t+5}\right) \equiv \sigma_{y}^{2}=\sigma_{x}^{2} y_{t}^{2}$, where $y_{t}$ is current real income, $\bar{x}$ is the expected growth rate of real income and $\sigma_{x}^{2}$ its variance.
} 
dix it can be seen that the structual parameters can be reasonably thought as stable $^{15}$, given that most of the determinants evolve slowly over the relevant time span (e.g., risk preferences, occupational and personal status, region of residence or having had health problems in the past). This procedure facilitates the comparison with previous results (Guiso et al., 1996) as well as to partially overcome the potential endogeneity problem of this measure, i.e. that more risk averse households hold both safer occupations and tend to participate less in the stock market (Lusardi, 1997). Criticisms to the use of this self-assessed measure of income risk are well-known: it is a sufficient indicator of risk for a very restrictive class of preferences, potentially underestimates the probability of very low income events and it is too low when compared to panel data estimates ${ }^{16}$.

(Table 2 here)

Table 2 reports descriptive statistics for the sample (columns 1 and 2), by the sign of self-assessed correlations (columns 3 and 4, for non-negative and negative correlations respectively) and for varying levels of earnings uncertainty (columns 5 and 6 , for low and high levels respectively). The sample average of the predicted income risk is $6.3 \%$, strikingly low when compared with the values from the precautionary savings literature, i.e. between $10 \%$ and $20 \%$ of the earnings' level (e.g. Deaton (1992) reports a standard error of $15 \%$ for next year expected earnings in the US), but of the same order of magnitude as in Guiso et al. (1992, 1996). A decomposition of the sample by varying levels of income uncertainty below and above the median of the predicted distribution (table 2, columns 5 and 6) confirms that households with higher uncertainty hold marginally less risky assets (Arrondel and Calvo (2002), Arrondel and Masson (2003)), are younger, financially poorer, earn less at work, have more irregular incomes (discrete income risk variable), are more often unemployed, are more risk averse (see below) and more often women, hold lower educational degrees but are better informed (as proxied by parents holding risky assets, and having access to internet), and are more often liquidity constrained than households in the low income risk group.

As suggested by the theory, a test of the proposition that undiversifiable earnings crowds households out of the stockmarket requires controlling for

\footnotetext{
${ }^{15} \mathrm{We}$ also need that the expectation of earnings uncertainty is positively correlated with current income uncertainty. An ordered probit confirms that both variables are significantly positively correlated.

${ }^{16}$ See Guiso et al. $(1992,1996)$ for further details, and Dominitz $(1998,2001)$ for a reassessment of those criticisms.
} 
its potential covariation with financial returns, as well as for all variables that determine the decision to invest in the stock market. To control for the correlation, a question in the survey asks households about the reasons that may lead big firms to downsize the labour force: a binding bankruptcy constraint (a positive correlation is assumed, $\rho>0$ ) or the expectation of a positive price impact on the firm's listed stocks (a negative correlation is attributed, $\rho<0)$. From table 2, $62 \%$ report a negative correlation, while $34 \%$ reports a positive one. The remaining $4 \%$ are non-respondents. The descriptive statistics in table 2 by the reported sign of the correlation, columns 3 and 4, show that households who assessed a negative correlation participate more often in the stock market (as predicted by the theory), are more risk averse (see below), work more often in a big firm and are considerably more educated ${ }^{17}$. This last point seems to be at odds with the current consensus that earnings of college educated household heads covariate positively with financial returns (Haliassos (2003), Haliassos and Michaelides (2003)), and if accepted, would relegate our variable to an informational proxy status. But Palacios-Huerta $(2001,2003)$ notices that standard panel data computations of the correlation have neglected the skill premium component of earnings. Since this skill premium is negatively correlated with the returns to domestic capital $^{18}$, taking it into account reverses the positive correlations obtained by Campbell (1996) for stockholders (see table 1 in Palacios-Huerta, 2001). Lustig and Van Nieuwerburgh (2006) also provide evidence of a robust negative correlation between human capital and financial returns in the $\mathrm{US}^{19}$.

\footnotetext{
${ }^{17}$ Unreported probit estimations confirm that those who have graduate studies $(+14 \%)$ and college education $(+11.9 \%)$ and work in a big firm $(+6.2 \%)$ tend to report a negative correlation assessment.

${ }^{18}$ Rubinstein and Tsiddon (2001) use the 1968-1992 PSID data on white males to show that higher educational attainments correspond to less cyclical unemployment, employment and wages. Furthermore, controlling for parents' educational levels, college graduates with educated parents face acyclical unemployment and wage increases in absolute terms during recessions, while the less educated with less educated parents face highly pro-cyclical wages and employment. See also Keane et al. (1988) for additional evidence along these lines.

${ }^{19}$ Botazzi et al. (1996) use OECD data for 16 countries from 1970 to 1992, and find significant negative covariation between innovations to human wealth and innovations to financial wealth, for all but 4 countries (Austria, Germany, Norway and US) including France (see tables 3, 4 and 5). This finding has been subsequently corroborated by Palacios-Huerta (2001), Julliard (2004, tables 1, 2 and 4) and more recently, by Santos and Veronesi (2005, tables 1, 2A, 2B, 3 and 4). Cocco et al. (2005) perform a Carroll and Samwick's (1997) labour income variance decomposition by educational levels on PSID
} 
Contrary to most of the existing studies, two different questions that proxy households' degree of risk aversion are available. The first mimics the methodology of Barsky et al. (1997) (see Appendix) and assumes that housholds risk preferences are in the constant relative risk aversion (CRRA) class: $8 \%$ of the sample has a CRRA coefficient lower than 1, 20\% has a CRRA between 1 and 2, 28\% has a CRRA between 2 and 3.76 and $37 \%$ has a risk aversion coefficient greater than $3.76\left({ }^{20}\right)$. The second is based on work by Guiso and Paiella (2001, 2004), who construct a measure of the coefficient of absolute risk aversion ${ }^{21}$. It asks individuals their maximum willingness to pay to enter a lottery representing a relatively large financial risk (around $16 \%$ of average annual income) ${ }^{22}$. We use the first to obtain estimates of the subjective income variance (because it was the only variable available in the 'Patrimoine 98' survey) and the second to estimate the probability of participation, since this variable has more explanatory power and it is continuous. More importantly, accounting for risk aversion significantly contributes to avoid endogeneity issues between occupational choice and financial risk taking attitudes ${ }^{23}$.

Finally, to capture households' ability to gain access to credit markets, two questions in the survey identify both 'discouraging borrowers' and 'turned down applicants'. The variable that proxies for liquidity constraints takes value one if households qualified themselves in either category, and is similar to the one used by Guiso et al. (1996). 481 of the 2460 surveyed households

data, to find statistically non significant negative correlation for both college educated and high school dropouts, while zero for high school attendants (see table 3 in their paper).

${ }^{20}$ The proportion of households in each CRRA coefficient bracket for the 35-55 year old subsample in the INSEE survey 'Patrimoine 98' (column 3, table A1 in appendix) are similar to those for the DELTA-TNS 2002 survey (column 2, table A1 in appendix).

${ }^{21}$ For sampled households, both measures are positively correlated though less than expected. The reason seems to stem in the different type of lotteries they propose to survey respondents: the first relates to lifetime labour income prospects, while the second proposes a financial investment opportunity. Arrondel et al. (2002) consider 'domain dependent' risk averse preferences.

${ }^{22} \mathrm{~A}$ potential drawback of this measure is that the magnitude of the risk is too large for a second order Taylor approximation to be accurate (it is claimed to be valid for small risks, i.e. between $1 \%$ and $5 \%$ of average income). This is to be traded-off against the inaccuracy of responses if the lottery is small, since expected utility maximizers are risk-neutral in the small (Rabin, 2000). Still, it is likely to be a poor measure for poorer individuals.

${ }^{23}$ In table 2, comparing columns 5 and 6 along the rows reporting the two risk aversion measures, those who are more risk averse perceive riskier incomes (see also Guiso and Paiella, 2004). 
are liquidity constrained $(20 \%)\left({ }^{24}\right)$. Households exposed to higher earnings risk (by both the discrete and predicted income risk proxies) are also more likely to be liquidity constrained, in line with theoretical predictions ${ }^{25}$.

\subsection{Empirical results}

For estimation purposes, we assume that households' indirect utility function can be written as a linear function of household $i$ observable characteristics $\mathbf{x}_{i}$, plus an error term $e_{i}$ normally distributed. The error term includes household-specific factors affecting her utility. Let $U_{i}^{s}=\boldsymbol{\beta}_{s}^{\prime} \mathbf{x}_{i}+e_{i}^{s}$ be the indirect utility function of stockholders, and $U_{i}^{0}=\boldsymbol{\beta}_{0}^{\prime} \mathbf{x}_{i}+e_{i}^{0}$ that of nonstockholders $(s=0)$. Since the indirect utility function cannot be observed, only participation status, we accordingly define the dichotomous variable $y_{i}$ that takes value 1 if the household participates, and 0 otherwise:

$$
\operatorname{Pr}\left(y_{i}=1 \mid \mathbf{x}_{i}\right)=\operatorname{Pr}\left(U_{i}^{s}-U_{i}^{0}>0\right)=\operatorname{Pr}\left(\boldsymbol{\beta}^{\prime} \mathbf{x}_{i}+e_{i}>0 \mid \mathbf{x}_{i}\right)=\boldsymbol{\Phi}\left(\boldsymbol{\beta}^{\prime} \mathbf{x}_{i}\right)
$$

where $\boldsymbol{\Phi}($.$) denotes the standard normal cumulative distribution function.$ The vector $\mathbf{x}_{i}$ contains a proxy for anticipated liquidity constraints $\left(c l_{i}\right)$, the expected variance of earnings $\left(\sigma_{i, y}^{2}\right)$, the coefficient of absolute risk aversion $\left(\gamma_{i}\right)$, the proxy of the subjectively assessed correlation $\left(\rho_{i}\right)$ and its interaction with income risk (see above), and a vector $\mathbf{w}_{i}$ of other variables previously demonstrated to be significant in explaining positive stockholdings such as age, gender, labour income, financial wealth, homeownership status, inter vivos or mortis causa transfers, and a set of variables that proxies for the stock of financial information (living in Paris, parents stockownership status and having acces to internet) $\left({ }^{26}\right)$. Since demographic factors give also an approximation of potential future sources of income risk the exclusion of which can lead to misspecification problems (Burgess et al., 2000), we include a dummy that takes value 1 if the household has children. Finally, to control

\footnotetext{
${ }^{24}$ Although the percentage seems strikingly high, it is not among the 35-55 year-old households when compared with the INSEE 'Patrimoine 1998' survey (13.25\%) or with the figure reported by Guiso et al. (1996) for the 1987 SHIW (15.6\%).

${ }^{25}$ Since those who are more likely to be liquidity constrained are also more likely to face higher income uncertainty, we control for potential endogneity problems (see next subsection).

${ }^{26}$ Arrondel and Masson $(1990,1996,2003)$ show that although fixed transactions and information costs are the main determinants of stockownership, they do not explain the amount of stocks held.
} 
for inertial factors (mainly incentive remuneration schemes) that may explain involuntary stockmarket paricipation, we also introduce the variable 'working in a big firm'. In specification (8), income risk is assumed to be exogenous.

If capital markets are imperfect (transaction or informational costs) households' income and wealth influences portfolio choice ${ }^{27}$. The empirical analysis reveals that their effect is best captured by a second order polynomial. Although this facilitates the comparison with existing results in the literature (Guiso et al. (1996, 2002, 2003), Haliassos and Bertaut (1995) or King and Leape (1998)), it has the disadvantage of introducing heteroscedasticity in the error term $e_{i}$ :

$$
\operatorname{Var}\left(e_{i} \mid \mathbf{x}_{i}, z_{i}\right)=\left[\exp \left(v^{\prime} z_{i}\right)\right]^{2}: z_{i} \equiv \text { Financial wealth }
$$

Table 3 reports the regression results of the heteroscedastic probit estimation ${ }^{28}$ by measures of income risk ${ }^{29}$. The variables have the expected signs with minor differences across columns. Financial wealth has a positive effect on participation and is significant at the $1 \%$ level. An increase in financial wealth from the first decile (6,500 euros) to the ninth decile (410,000 euros) increases the probability of participation by $25 \%$. Income also increases the probability of participation in the stock market, moving from the first to the ninth decile increases the probability of stockownership by $7 \%$. The effects are consistent with fixed transaction and information costs of accessing the stock market, as well as of decreasing aversion to financial risk taking, since both capture households' initial endowments other than housing. Homeownership status has a positive and significant effect, increasing the probability of participation by $7 \%$. Heaton and Lucas (2000) rationalize this finding by means of the negative correlation detected between housing and financial risks, i.e. owning a house serves as a hedge against financial fluctuations ${ }^{30}$

\footnotetext{
${ }^{27}$ See King and Leape $(1987,1998)$ and simulated results by Cocco et al. (2005) or Haliassos and Michaelides (2003).

${ }^{28}$ The Likelihhood Ratio test (LR) is distributed as a $\chi^{2}(1)$ and for each different measure of income risk considered, we cannot reject the null hypothesis of no heteroscedasticity. Under the alternative hypothesis, the estimated coefficients have the same sign and are similar in magnitude.

${ }^{29}$ Results in Table 3 only refer to direct and indirect stockownership. But the sign and magnitude of the reported estimates are robust to changes in the definition of stockownership (only direct stockholders) and occupational status (subsample of only active households). They are also robust to a semi-log specification in income and financial wealth.

${ }^{30} \mathrm{~A}$ potential endogeneity bias may also explain the positive effect, if we consider the
} 
(see also Brueckner (1997) or Flavin and Yamashita (2002)). But it can also be interpreted as a proxy for total wealth if trasaction costs are present, so that homeowners are less risk averse because they are wealthier.

(Table 3 here)

Previous empirical studies find that education increases the probability of participation. We excluded it because of its strong correlation with income and the set of information variables. More information significantly increases the probability of participation: Having Internet at home ${ }^{31}$ raises the probability of participation by $11 \%$ and if parents hold risky assets, the probability increases to $16 \%\left({ }^{32}\right)$. Households living in Paris are $13 \%$ more likely to hold risky assets. The age variables indicate that the probability of owning risky assets is lower for younger households, although it has a hump-shaped effect reaching its maximum at the age of 46 . Younger individuals are less informed (King and Leape, 1987) tend to be more often liquidity constrained (Cocco et al. (2005), Haliassos and Michaelides (2003), Viceira (2001)) and have a stronger preference for homeownership (Flavin and Yamashita (2002)) but enjoy greater labour supply flexibility (Bodie et al. (1992), Chan and Viceira (2000)). But the reduction in the probability of stockownership after 46 is difficult to explain by life cycle motives alone ${ }^{33}$.

In accordance with theoretical predictions, more risk averse individuals have a lower probability of participation ${ }^{34}$. Surprisingly, once we control for risk aversion, being a woman significantly reduces the probability of being a stockholder (by a 8\%), confirming the results obtained by Schubert et al. (1999). Households with children are 3\% less likely to invest in the stock market. Having received an inheritance or inter vivos transfers increases the probability of participation ( $6 \%$ and $3 \%$ respectively), but the latter is only

choice of the house. However, this is rather unlikely given the illiquid nature of the asset in France, and that most households do not buy it for investment purposes.

${ }^{31}$ The positive effect of information on the probability of holding stocks, as proxied by having internet access has recently been documented by Bogan (2006) for the US.

${ }^{32}$ Chiteji and Stafford (2000) or Vissing-Jorgensen (2003) obtain similar results: when parents are stockholders, children have a higher probability of becoming stockholders because informational barriers are smaller.

${ }^{33}$ The age coefficients are difficult to interpret also because only individuals between 35 and 55 were interviewed.

${ }^{34}$ We have tested the two available variables that capture risk aversion. We have chosen the continuous variable based on Guiso and Paiella (2001, 2004) because it has more explanatory power, its wording is closely related to financial risk taking and the CRRA variable is used as a predictor in the income risk estimation. 
significant at $10 \%$.

Households who have been liquidity constrained or who think that they will be so in the future are less likely to participate (around 13\%). The effect of liquidity constraints reinforces the risk substitution effect, in line with the empirical results obtained by Guiso et al. (1996) and with theoretical predictions. Gollier (2001) proves that the willigness to take risk is reduced in the presence of a liquidity constraint if absolute risk tolerance is increasing and convex in wealth. Koo's (1999) theorem 2 (iii) states that liquidity constrained households invest strictly less in risky assets than households who are not constrained, because their risk tolerance is smaller. Deaton (1992) explains how the expectation of being liquidity constrained in the future leads prudent households to save more ('buffer stock'), while Elmendorf and Kimball (2000) prove that the positive wealth effect of increased precautionary savings that leads decreasing risk averse (DARA) households to invest more in stocks is dominated by the negative increase in risk if households are also decreasingly prudent (DAP), resulting in an overall reduction in stockownership.

To avoid a possible endogeneity bias of the liquidity dummy, we conducted Davidson and MacKinnon's (1993) test. The instruments used in the auxiliary IV regression are: squared log of income, education, marital status, health status, a dummy variable for those individuals who have asked for a credit and labour status. We also tested the validity of the instruments, and the null hypothesis of exogeneity of the regressors cannot be rejected ${ }^{35}$.

The available correlation proxy is an imperfect assessment of individual earnings' degree of covariation with rate of return risk. Still it has the advantage of being self-assessed, and behaves empirically in accordance with the theoretical predictions: households who assess a negative sign, $\rho<0$, are 9 percentage points more likely to participate (at $1 \%$ level of significance, in both columns 1 and 2, table 3). A possible interpretation comes from Botazzi et al. (1996) or Danthine and Donaldson (2002): a negative average correlation indicates that redistributive shocks dominate over the cycle. In accordance with this observation, individuals reporting a negative correlation answered that 'big firms fire employees because they want to increase the price of their stockmarket shares'. A probit regression of the probability

\footnotetext{
${ }^{35}$ Instruments appear individually and jointly significant, with a $\chi^{2}(11)$ statistic of 33.41 and a P-value of 0.005. See also Robin (2000) for further details. The results are available from the authors upon request.
} 
to assess a negative sign confirms 'working in a big firm' and having received college education or above as the two main determinants. Another possible interpretation in terms of the skill premium content of wages rationalizes the second main determinant: educated individuals tend to have counter-cyclical labour earnings (Rubinstein and Tsiddon, 2001), and therefore have a higher propensity to become stockowners because the returns to human capital are negatively correlated with the stock market (Palacios-Huerta, 2001) ${ }^{36}$ ). The skill premium interpretation is consistent with the descriptive evidence in the bottom row of table 2: college educated households (last two rows) tend to report a negative sign (columns 3 and 4) and have lower income risk (columns 5 and 6), while less than college educated ones (rows three to five from the bottom) tend to report a non-negative sign (columns 3 and 4) and have higher income risk (columns 5 and 6 ). While other recent studies have not been able to find evidence of a correlation effect using longitudinal individual data (e.g. Vissing-Jorgensen (2002) or Massa and Simonov (2006)), none of them has considered the potential skill premium content of wages that is consistent with our self-assessed correlation proxy.

Column 1 reports the estimation results using the discrete income risk dummy. A one is assigned to those who report either irregular or a mix of regular and irregular household earnings, while a zero is attributed otherwise. Contrary to available empirical evidence for the US (Vissig-Jorgensen (2002), Campbell and Viceira (2002)), Italy (Guiso et al., 1996) or Sweden (Massa and Simonov, 2006) and economic theory predictions, it has no significant effect $^{37}$. The absence of a negative effect is confirmed by the results in column 2 , where the predicted measure of the subjective earnings variance substitutes the discrete income risk variable, to take into account heterogeneity in earnings risk exposure ${ }^{38}$.

\footnotetext{
${ }^{36}$ Yet a third interpretation in terms of the informational content of unemployment news on equity returns is possible: bad unemployment news are interpreted as "good news" during expansions, but as bad news during recessions (Boyd et al. (2005), Andersen et al. (2005)). But the underlying idea is the one of redistributive shocks, just that they are state-contingent.

${ }^{37}$ But in line with previous empirical results for France (Arrondel and Calvo (2002) or Arrondel and Masson (2003)) and Alessie and Hochguertel (2003) for The Netherlands.

${ }^{38}$ Although the variance is a partial representation of risk, we considered alternative measures like the probability of being unemployed five years ahead, a dummy for households that assign point estimates to reductions in real earnings, and different dispersion measures of the subjectively assessed individual distributions. For none of them a coefficient significantly different from zero was obtained.
} 
Finally, in column 3 we decompose the effect of expected income risk using the self-assessed correlation proxy to separate those who assess a negative sign $(\rho<0)$ from the rest $(\rho \geq 0)$. Since the correlation is likely to be more important for those households who face higher earnings uncertainty, we introduce the interaction of both. In line with the theoretical results of section 2, for those households whose earnings are negatively correlated the effect on participation is ambiguous: they tend to participate less to the extent that their labour income is risky, but tend to participate more to the extent that it is negatively correlated and can use the stock market as a hedge against fluctuations in their earnings. Consistently, a positive but insignificant coefficient (at 10\%) is obtained empirically. As well, for those who assess a non-negative correlation, from section 2 we know that both the income risk and the correlation effect go in the same direction. Overall a negative impact on participation is obtained (significant at 5\%): The point estimate implies that households reporting a non-negative correlation are 4.45 percentage points less likely to hold risky assets than households reporting a negative sign. For those households who assess a non-negative sign, moving a household from the 10th percentile of relative income risk to the 90th percentile, decreases the probability of holding assets by 4.3 percentage points, all other things being equal. Therefore when controlling for the correlation, we do find evidence of a negative impact of uninsurable earnings risk on stockownership.

\section{Conclusion}

There has been a resurgent interest on the implications of incomplete markets for portfolio choice theory motivated by the number of portfolio puzzles identified in the literature. One of the most active research areas has concentrated on the study of the determinants of stock market participation and stockholdings. Considerable progress has been made in understanding the interactions between income risk, rate of return risk, borrowing constraints and transactions costs. Using measures proxying for income risk and liquidity constraints available in the literature, we test whether they affect the stockownership decision controlling for the correlation between earnings and rate of return risk as self-assessed by households. Exploiting the 'DELTA-TNS 2002' household survey, the empirical results confirm the theoretical prediction that non-negatively correlated background risks reduce the willingness 
to bear financial risk, crowding households out from the stock market. As well, we do find evidence that borrowing and liquidity constraints reduce households' propensity to invest in risky assets.

Quantitatively, the effects identified confirm the relative importance of the different factors as obtained in the literature: transactions costs and informational barriers, liquidity constraints, taste for risk parameters and income risk. Each of them is, by decreasing order of magnitude, important to explain households' decisions to enter the stock market. 


\section{References}

[1] Alessie, R., Hochguertel, S. and van Soest, A. (2002). "Household Portfolios in The Netherlands", in Household Portfolios, Guiso L., Haliassos M. and T. Japelli eds, MIT Press.

[2] Andersen, T. G., Bollerslev, T., Diebold, F. X., and Vega, C. (2005). "Real-time Price Discovery in Stock, Bond and Foreign Exchange Markets", NBER WP 11312.

[3] Arrondel, L. (2002). "Risk Management and Wealth Accumulation Behavior in France", Economics Letters, vol. 74, pp. 187-194.

[4] Arrondel L. (2003)(ed.), Epargne, Assurance-Vie et Retraite, Economica, Paris.

[5] Arrondel L. and Calvo Pardo, H. (2002). "Temperant Portfolio Choice with a Correlated Background Risk", DELTA DP n² 2002-16.

[6] Arrondel, L. and Masson, A. (1990). "Hypothèse du cycle de vie, diversification et composition du patrimoine", Annales d'Economie et de Statistique, $\mathrm{n}^{\circ} 17$, pp. 1-45.

[7] Arrondel, L. and Masson, A. (1996). "Gestion du risque et comportements patrimoniaux", Economie et Statistique, n²96-297, pp. 63-89.

[8] Arrondel, L. and Masson, A. (2003). "Stockholding in France", in Stocholding in Europe, Guiso L., Haliassos M. and T. Jappelli eds, Palgrave, Hampshire.

[9] Arrondel, L. and Lollivier, S. (2004). "Transaction costs, Income Risk and Household Portfolio Allocation: Evidence from French Panel Data," DELTA DP n 2004-19.

[10] Arrondel, L., Masson, A., Verger, D. (2002). "Comportement face au risque et à l'avenir et accumulation patrimoniale: bilan d'une expérimentation", INSEE DP (Série méthodologie de Collecte) n C0201.

[11] Arrow, K. J. (1965). Aspects of the Theory of Risk Bearing, Yrjo Jahnsson Lectures, The Academic Book Store, Helsinki. 
[12] Barsky, R. B., Juster, T. F., Kimball, M. S. and Shapiro, M. D. (1997), "Preference Parameters and Behavioral Heterogeneity : an Experimental Approach in the Health and Retirement Study", Quarterly Journal of Economics, Vol. CXII, pp. 537-580.

[13] Bodie, Z., Merton, R. C. and Samuelson, W. F. (1992). "Labor Supply Flexibility and Portfolio Choice in a Life-cycle Model", Journal of Economic Dynamics and Control, vol. 16, pp. 427-449.

[14] Bogan, V. (2006). "Stock Market Participation and the Internet", WP 2006-10, Dept. of Applied Economics and Management, Cornell University.

[15] Bottazzi, L., Pesenti, P. and van Wincoop, E. (1996). "Wages, Profits and the International Portfolio Puzzle", European Economic Review, vol. 40, pp. 219-254.

[16] Boyd, J. H., Jagannathan, R. and Hu, J. (2005), "The Stock Market's Reaction to Unemployment News: Why Bad News Is Usually Good For Stocks," Journal of Finance, forthcoming.

[17] Brandt, M. (2004), "Portfolio Choice Problems", forthcoming in the Handbook of Financial Econometrics, Y. Aït-Sahalia and L.P. Hansen Eds., Elsevier Science: Amsterdam.

[18] Brueckner, J. (1997), "Consumption and Investment Motives and the Portfolio Choices of Homeowners", Journal of Real Estate Finance and Economics, vol.15 (2), pp. 159-180.

[19] Burgess S., Gardiner, K., Jenkins, S.P., and Propper, C. (2000). "Measuring Income Risk", CASE paper 40, Centre for Analysis of Social Exclusion, London School of Economics.

[20] Campbell, J.Y. (1996). "Understanding Risk and Return", Journal of Political Economy, vol.104, pp. 298-345.

[21] Campbell, J.Y. and Viceira, L. M. (2002). Strategic Asset Allocation: Portfolio Choice for Long-Term Investors, Clarendon, Lectures in Economics, Oxford University Press. 
[22] Carroll, C. D., and Samwick, A. A., (1997). "The Nature of Precautionary Wealth", Journal of Monetary Economics 40: 41-71.

[23] Chan, Y. L. and Viceira, L. M. (2000). "Asset Allocation with Endogenous Labor Income: The Case of Incomplete Markets". Available at http://papers.ssrn.com/sol3/papers.cfm?abstract_id=254568

[24] Chiteji, N. S. and F. P. Stafford (2000). "Asset Ownership Across Generations", Population Studies Center at the Institute for Social Research, University of Michigan, Research Report No. 00-454.

[25] Cocco, J., Gomes, F. and Maenhout, P. (2005). "Cosumption and Portfolio Choice Over the Life-Cycle", The Review of Financial Studies 18, pp. 491-533.

[26] Cochrane, J. H. (2006), "Financial Markets and the Real Economy", mimeo U. of Chicago.

[27] Danthine, J.-P. and Donaldson, J.B. (2002). "Labour Relations and Asset Returns", Review of Economic Studies, vol. 69, pp. 41-64.

[28] Davidson, R. and MacKinnon, J.G. (1993). Estimation and Inference in Econometrics, Oxford University Press.

[29] Davis, S.J. and Willen, P. (2000). "Occupation-Level Income Shocks and Asset Returns: their Covariance and Implications for Portfolio Choice", NBER WP 7905.

[30] Deaton, A. (1992) Understanding Consumption, Oxford : Oxford University Press.

[31] Dominitz, J. (1998). "Earnings Expectations, Revisions and Realizations", Review of Economics and Statistics 80, pp. 389-398.

[32] Dominitz, J. (2001). "Estimation of Income Expectations Models using Expectations and Realizations Data", Journal of Econometrics 102, pp. 165-195.

[33] Dominitz, J. and Manski, C. (1997). "Using Expectations Data to study Subjective Income Expectations", Journal of the American Statistical Association 92, pp. 855-867. 
[34] Drèze, J. H. and Modigliani, F. (1966). "Epargne et consommation en avenir aléatoire", Cahier du Séminaire d'Econométrie, nº 9, pp. 7-33.

[35] Drèze, J. H. and Modigliani, F. (1972). "Consumption under Uncertainty", Journal of Economic Theory, vol. 5, pp. 308-335.

[36] Eeckhoudt, L., Gollier, C. (2000). "The Effects of Changes in Risk on Risk Taking: a Survey", mimeo, Toulouse.

[37] Eeckhoudt, L., Gollier, C. (2001). "Are Independent Optimal Risks Substitutes?", mimeo, Toulouse.

[38] Eeckhoudt, L. and Schlesinger, H. (2006). "Putting Risk in its Proper Place", American Economic Review 96, pp. 280-289.

[39] Eeckhoudt, L., Gollier, C. and Schlesinger, H. (1996). "Changes in Background Risk and Risk Taking Behavior", Econometrica, vol. 64, pp. 683-689.

[40] Elmendorf, D. W. and Kimball, M. S. (2000). "Taxation of Labour Income and the Demand for Risky Assets", International Economic Review, vol. 41, pp. 801-832.

[41] Flavin, M. and Yamashita, T. (2002), "Owner-Occupied Housing and the Composition of the Household Portfolio", American Economic Review, vol. 92, pp. 345-362.

[42] Friedman, M. (1957), A Theory of the Consumption Function, Princeton : Princeton University Press.

[43] Givord, P. and Maurin, E. (2004). "Changes in Job Security and their Causes: An Empirical Analysis Method applied to France, 1982-2000", European Economic Review 48, pp. 595-617.

[44] Gollier, C. (2001). The Economics of Risk and Time, MIT Press, Cambridge.

[45] Gollier, C. and Pratt, J. W. (1996). "Weak Proper Risk Aversion and the Tempering Effect of Background Risk", Econometrica, vol. 64, pp. 1109-1123. 
[46] Gollier, C. and Zeckhauser R. (1997). "Time Horizon and Portfolio Risk", Journal of Risk and Uncertainty, (forthcoming).

[47] Gourieroux, C., Monfort, A., and Trognon, A. (1987). "Simulated Residuals", Journal of Econometrics, vol. 34, pp. 201-252.

[48] Gruber, J. (1997). "The Consumption Smoothing Benefits of Unemployment Insurance", American Economic Review, vol. 87, pp. 192-205.

[49] Guiso, L. and Jappelli, T. (1998), "Background uncertainty and the demand for insurance against insurable risk", The Geneva Papers on Risk and Insurance Theory, vol. 23, pp. 7-27.

[50] Guiso L. and Paiella, M. (2001), "Risk Aversion, Wealth and Background Risk", CEPR DP2728.

[51] Guiso L. and Paiella, M. (2004), "The Role of Risk Aversionin Predicting Individual Behaviours", CEPR DP4591.

[52] Guiso, L., Jappelli, T. and Terlizzese, D. (1992). "Earnings Uncertainty and Precautionary Saving", Journal of Monetary Economics, vol. 30, pp. 307-338.

[53] Guiso, L., Jappelli, T. and Terlizzese, D. (1996). "Income Risk, Borrowing Constraints and Portfolio Choice", American Economic Review, vol. 86, pp. $158-172$.

[54] Guiso L., Jappelli, T. and Haliassos, M. (2002), Household Portfolios, MIT Press, Cambridge.

[55] Guiso L., Jappelli, T. and Haliassos, M. (2003), Stockholding in Europe, Palgrave Macmillan, Hampshire.

[56] Haliassos, M. (2003). "Stockholding: Lessons from Theory and Computations", in Stockholding in Europe, Guiso L., Haliassos M. and T. Japelli eds, Palgrave, Hampshire.

[57] Haliassos, M. and Bertaut, C. (1995), "Why Do So Few Hold Stocks?", Economic Journal, vol. 105, pp. 1110-1129.

[58] Haliassos, M. and Michaelides, A. (2003), 'Portfolio Choice and Liquidity Constraints', International Economic Review, vol.44, pp.143-178. 
[59] Heaton J. and Lucas, D. (1996), "Evaluating the Effects of Incomplete Markets on Risk-Sharing and Asset Prices", Journal of Political Economy, vol. 104, pp. 443-487.

[60] Heaton J. and Lucas, D. (2000), "Portfolio Choice in the Presence of Background Risk", Economic Journal, vol. 110, pp. 1-26.

[61] Hochguertel, S. (1998). "Households' Portfolio Choices", Tilburg, CentER Dissertation Series, $n^{\circ} 38$.

[62] Julliard, C. (2004), "Labor Income Risk and Asset Returns", mimeo Princeton.

[63] Kapteyn, A. and Teppa, F. (2002). "Subjective Measures of Risk Aversion and Portfolio Choice", CENter DP n²002-11, Tilburg.

[64] Katz, L. F. and Autor, D.H. (1999). "Changes in the Wage Structure and Earnings Inequality", Handbook of Labor Economics, vol. 3A, pp. 1463-1555. Amsterdam: North-Holland Press.

[65] Keane, M., Moffit, R. and Runkle, D. (1988), "Real Wages over the Business Cycle: Estimating the Impact of Heterogeneity with Micro Data", Journal of Political Economy 96, pp. 1232-1266.

[66] Kihlstrom, R.E., Romer, D. and Williams, S. (1981). "Risk Aversion with Random Initial Wealth", Econometrica, vol. 49, pp. 911-920.

[67] Kimball, M. S. (1990). "Precautionary Saving in the Small and in the Large", Econometrica, vol. 58, pp. 53-73.

[68] Kimball, M. S. (1993). "Standard Risk Aversion", Econometrica, vol. 61, pp. 589-611.

[69] King, M. A. and Leape, J. I. (1987) "Asset Accumulation, Information, and the Life Cycle", N.B.E.R. WP2392.

[70] King, M. A. and Leape, J. I. (1998). "Wealth and Portfolio Composition: Theory and Evidence", Journal of Public Economics, vol. 69, pp. 155193. 
[71] Koo, H.K. (1999). "Consumption and Portfolio Selection with Labor Income: A Discrete-Time Approach", Mathematical methods of Operations Research 50, pp. 219-243.

[72] Letendre, M-A and Smith G. W. (2001). "Precautionary Saving and Portfolio Allocation: DP by GMM", Journal of Monetary Economics 48, pp. 197-215.

[73] Lustig, H. and Van Nieuwerburgh, S. (2006), "The Returns on Human Capital: Good News on Wall Street is Bad News on Main Street", forthcoming in The Review of Financial Studies.

[74] Lusardi, A. (1997). "Precautionary Saving and Subjective Earnings Variance", Economics Letters, vol. 57, pp. 319-326.

[75] Mankiw, N.G. and Zeldes, S. (1991). "The Consumption of Stockholders and Non-stockholders", Journal of Financial Economics, vol. 29, pp. 97112.

[76] Manski, C.F. (2003). "Inference on Expectations and Decisions", Fischer-Schultz Lecture of the 2003 Econometric Society European Meeting in Stockholm, Sweden.

[77] Massa, M. and Simonov, A. (2006), "Hedging, Familiarity and Portfolio Choice", The Review of Financial Studies 19, pp. 633-685.

[78] Merton, R. C. (1971). "Optimal Consumption and Portfolio Rules in a Continuous Time Model", Journal of Economic Theory, vol. 3, pp. 373-413.

[79] Miniaci R. and Weber, G. (2002). "Econometric Issues in the Estimation of Household Portfolio Models", in Household Portfolios, Guiso L., Haliassos M. and T. Jappelli eds, MIT Press.

[80] Pratt, J. (1964). "Risk aversion in the small and in the large", Econometrica, vol. 32, pp. 122-136.

[81] Pratt, J. and Zeckhauser, R. (1987). "Proper Risk Aversion", Econometrica, vol. 55, pp. 143-154. 
[82] Palacios-Huerta, I. (2001), "The Human Capital of Stockholders and the International Diversification Puzzle", Journal of International Economics 54, pp. 309-331.

[83] Palacios-Huerta, I. (2003), "An Empirical Analysis of the Risk Properties of Human Capital Returns", The American Economic Review 93, pp. 948-964.

[84] Rabin, M. (2000). "Risk Aversion and Expected Utility Theory: A Calibration Theorem", Econometrica 68, pp. 1281-1292.

[85] Robin, J. M. (2000). "Modèles structurels et variables explicatives endogènes", Doc. Méthodologie statistique n²002, INSEE, Paris.

[86] Ross, S. A. (1981), "Some Stronger Measures of Risk Aversion in the Small and in the Large with Applications", Econometrica vol. 49, pp. 621-638.

[87] Rubinstein, Y. and Tsiddon, D. (2001), "Born to be Unemployed: Unemployment and Wages over the Business Cycle", mimeo U. of Chicago.

[88] Santos, T. and Veronesi, P. (2005), "Labor Income and Predictable Stock Returns", The Review of Financial Studies 19, pp. 1-44.

[89] Schubert R., Brown, M., Gysler, M., and Brachinger, H.W. (1999), "Financial Decision making: Are Women more Risk Averse?", American Economic Review vol. 89, pp. 381-385.

[90] Skinner, J. (1988), "Risky Income, Life Cycle Consumption and Precautionary Savings", Journal of Monetary Economics, vol. 22, pp. 237-255.

[91] Viceira, L.M. (2001), "Optimal Portfolio Choice for Long-Horizon Investors with Non-Tradable Labor Income", The Journal of Finance 55: 433-470.

[92] Vissing-Jorgensen, A. (2002). "Towards an explanation of Household Portfolio Choice Heterogeneity: Nonfinancial Income and Participation Cost Structures", N.B.E.R. WP8884.

[93] Vissing-Jorgensen, A. (2003). "Perspective on Behavioural Finance: Does "Irrationality" Disappear with Wealth? Evidence from Expectations and Actions", N.B.E.R. Macroeconomics Annual 2003. 


\section{Appendix}

Financial wealth: in the survey the individual is asked to say in which of the 8 predefined available brackets is her family. Since we are interested in a continuous measure we have used the simulated residual method (Gouriéroux et al., 1987). We have regressed an ordered probit of the financial wealth on some household characteristics. Once we have the estimated financial wealth a normally distributed error is added. After that, we check if the value falls inside the bracket chosen by the individual. If not, another normal error is added and so on until we predict the true interval. Doing so allows us to overcome the non-response problem for some households. If there is a missing value, the predicted value plus a normal error is directly used. The financial wealth is given in francs.

Income: for the income of the household the survey has a discrete variable of 13 brackets. The procedure described in the last paragraph to transform it into a continuous variable has been used too. Income refers to the household's annual income in French francs.

Income risk: Since the new survey has no information about different levels of income risk ${ }^{39}$, we use information from the 'Patrimoine 98' survey to discover the determinants of expected income risk. In the 'Patrimoine 98' survey a proxy for the subjective variance of households' income was constructed, following the methodology carried out by the Bank of Italy in 'SHIW 1989'. It asks households to distribute 100 points between different scenarios regarding the evolution of income in the next five years (see Guiso et al., $(1992,1996)$ or Arrondel and Calvo (2002)). We then use the estimated coefficients to predict each household's income risk, in our 'DELTA-TNS 2002' sample. Table A1 reports the estimation results.

(Table A1 here)

The estimates indicate that high income risk households earn more at work, are younger, more risk averse, have a preference for risk in financial investments, are more often unemployed, have/had health problems, tend to co-habitate rather than marry, and have children. There are 8 regional dummies to control for labour supply differences across regions, and 8 occu-

\footnotetext{
${ }^{39}$ There is just a qualitative question about income risk which, in tables 2 and 3 , is labelled 'discrete income risk'. It is a dummy variable constructed from the survey question. The survey asks if the household perceives a regular income, an irregular one, or a mix of both. The dummy variable takes value 1 if the household either answers 'irregular' or 'a mix of both'.
} 
pational dummies to capture heterogeneity in professional tastes.

Table A1 also reports sample means of the variables used to impute income risk. The 'Patrimoine 98 (ages 35-55)' and 'DELTA-TNS 2002' variables can be directly compared, showing similar characteristics. The main differences are: a lower proportion of surveyed households with children and graduate studies, and a higher fraction of risk averters and a positive taste for financial risk taking, relative to the 'Patrimoine 98 (ages 35-55)' mean variables. This increased preference for stockholding might be explained by the dotcom driven stock market boom that took place between 1998 and 2002, in most OECD economies.

\section{Measuring Relative Risk Aversion}

To obtain a measure of risk aversion, we asked individuals about their willingness to gamble on lifetime income (see the Appendix) according to the methodology of Barsky et al. (1997). The "game" resides in determining sequentially whether the interviewee would accept to give up his present income and to accept other contracts, in the form of lotteries: he has one chance in two to double his income, and one chance in two for it to be reduced by one third (contract $\mathrm{A})$, by one half (contract $\mathrm{B}$ ), and by one fifth (contract C). More precisely, the question in the survey was: 'Suppose that you have a job which guarantees for life your household's current income $R$. Other companies offer you various contracts which have one chance out of two (50\%) to provide you with a higher income and one chance out of two (50\%) to provide you with a lower income.

Are you prepared to accept Contract A which has $50 \%$ chances to double your income $R$ and $50 \%$ chances that your income will be reduced by one third?

For those who answer YES : the Contract $A$ is no longer available. You are offered Contract B instead which has $50 \%$ chances to double your income $R$ and $50 \%$ chances that it will be reduced by one half. Are you prepared to accept?

For those who answer NO : you have refused Contract A. You are offered Contract $C$. which has 50\% chances to double your income $R$ and $50 \%$ chances that it will be reduced by 20\%. Are you prepared to accept?'

This allows us to obtain a range measure of relative risk aversion under the assumption that preferences are strictly risk averse and utility is of the CRRA type. The degree of relative risk aversion is less than 1 if the individual successively accepts contracts A and B; between 1 and 2 if he accepts A but refuses B; between 2 and 3.76 if he refuses A but accepts $\mathrm{C}$; and finally more 
than 3.76 if he refuses both A and C. Among the 2460 households, 172 did not answer, 886 displayed a relative risk aversion lower than 1, 689 between 1 and 2, 517 between 2 and 3.76, and for 195 households relative risk aversion was larger than 3.76 .

Absolute risk aversion: the survey asks the following: 'if someone proposes you to invest in a place where you have one chance out of two to win 5000 euros and one chance out of two of losing the capital invested. How much (as a maximum) will you invest?'. Guiso and Paiella $(2001,2004)$ show that absolute risk aversion can be computed as: $A_{i}\left(w_{i}\right)=2 \frac{5000-Z_{i}}{5000^{2}+Z_{i}^{2}}$, where $A_{i}$ is the absolute risk aversion and $Z_{i}$ is the amount that the individual declares to be willing to invest. Risk-averse are those who declare $Z_{i}<5000$, riskneutral if $Z_{i}=5000$, and risk-lovers when $Z_{i}>5000$. For details concerning the validity of the approximation, we address the reader to their work.

\section{(Table A2 here)}

To estimate how risk aversion varies with consumers attributes, we have regressed the measure of absolute risk aversion on observable characteristics that can proxy for differences in tastes ${ }^{40}$. In line with their results, table 2 shows that risk aversion decreases with households' financial wealth. This provides further support to temperant risk behaviour, that requires decreasing absolute risk averse houshold preferences. Contrary to the results of Guiso and Paiella (2001) for Italy, no significant differences between living in different regions ${ }^{41}$ or having different ages are obtained. Instead, we find that absolute risk aversion depends on gender, having children and level of education. Being a woman ${ }^{42}$ and having children increases risk aversion as well as being poorly educated. Surprisingly, the fact that the individual has been unemployed in the past or is likely to be so in the future ${ }^{43}$ has no effect on risk aversion. Since residuals are far from being normally distributed, bootstrapped standard errors are provided in table A2.

Liquidity constraints: Households are asked two questions aimed at

\footnotetext{
${ }^{40}$ The results included in table A 2 replicate the one developed by Guiso and Paiella (2001) with the exception of father's characteristics, information which is not available in our survey.

${ }^{41}$ In table 3 we use a dummy for living in Paris which is not statistically significant. But we also included a dummy variable for each 'département' and they were not jointly significant (results reported upon request).

${ }^{42}$ Schubert et al. (1999) find empirical evidence of women being more risk averse.

${ }^{43}$ We do not include in the results of table 2 both unemployment variables because the two are highly correlated and multicollinearity problems emerge.
} 
measuring their ability to get access to the credit market. These questions are similar to those of the SHIW Italian survey (Guiso et al. 1996). We classify consumers as being liquidity constrained if they respond positively to at least one of the two following questions. The first indicates whether a consumer is a "discouraging borrower", the second whether he is a "turned down applicant":

- Did you renounce to finance expenditures on durable goods (main residence, cars ...) or did you renounce to restore your home because you expected that bank or other financial intermediaries will refuse the loan or the mortgage?

- Did you renounce to finance expenditures on durable goods (main residence, cars ...) or did you renounce to restore your home because bank or other financial intermediaries refused the loan or the mortgage?

In our 'DELTA-TNS 2002' survey, 481 households are liquidity constrained ( $20 \%$ of the sample), slightly above the average proportion reported by similar studies. The reason is that we only sample households whose head is between 35 and 55 years old (Arrondel, 2003).

Correlation between stock prices and income risk: there is a question in the survey that asks directly to individuals: 'In your opinion, big firms fire employees when' and the options are: 'when the firm is in financial trouble' or 'when the firm wants to increase its stock market price'. If the individual responds, 'when the firm is in financial trouble', a positive correlation is assumed between the exogenous income risk and the endogenous stock market risk $(\rho>0)$; the correlation is negative $(\rho<0)$ if the individual answers 'when the firm wants to increase its stock market price' and we assume that there is no correlation $(\rho=0)$ when there is no answer. 
Table 1: 'DELTA-TNS 2002' Households' Financial Assets ${ }^{(1)}$

Percentage Holding the Asset (TNS 2002)

Financial assets

(1)

Cash, transactions and savings accounts

84.6

Homeownership savings (and current) accounts

61.1

Bonds

4.6

Stocks from privatized public companies

20.8

Other stocks

17.6

Stocks of foreign firms

4.3

Mutual funds and managed investment accounts $\quad 12.0$

Life insurance contracts $\quad 46.9$

Annuities $\quad 17.6$

Contributions to Complementary Pension Plans $\quad 20.8$

\section{Stockholdings:}

-Direct ${ }^{(2)}$

-Direct and Indirect ${ }^{(3)}$

Source: 'DELTA - TNS 2002'.

(1) The sample only includes households whose head is between 35 and 55 years old.

(2) Direct: the household holds stocks of privatised, foreign or other firms publicly listed.

(3) Direct and Indirect: the household holds equities directly (includes national and foreign stocks) and indirectly (through mutual funds). 
Table 2: Sample characteristics 'DELTA - TNS 2002'(1)

\begin{tabular}{|c|c|c|c|c|c|c|}
\hline \multirow[b]{2}{*}{ Continuous variables } & \multicolumn{2}{|c|}{ Whole sample } & \multirow{2}{*}{$\begin{array}{c}\text { Non-Neg. } \\
\text { corr. } \\
(\rho \geq 0) \\
(3)\end{array}$} & \multirow{2}{*}{$\begin{array}{l}\text { Neg. corr. } \\
\begin{array}{c}(\rho<0) \\
(4)\end{array}\end{array}$} & \multirow{2}{*}{$\begin{array}{c}\text { Low- } \\
\text { income } \\
\text { risk }^{(8)} \\
(5)\end{array}$} & \multirow{2}{*}{$\begin{array}{c}\text { High- } \\
\text { income } \\
\text { risk }^{(8)} \\
(6) \\
\end{array}$} \\
\hline & $\begin{array}{c}\text { Mean } \\
(1)\end{array}$ & $\begin{array}{l}\text { Std. Dev. } \\
\text { (2) }\end{array}$ & & & & \\
\hline Financial wealth ${ }^{(2)}$ (3) & 169,409 & $1,111,641$ & 220,190 & 137,804 & 198,642 & 140,177 \\
\hline Income $^{(2)(4)}$ & 202,067 & 256,637 & 204,419 & 200,605 & 234,016 & 170,120 \\
\hline Income risk $^{(2)(5)}$ & 11,920 & 12,127 & 11,949 & 11,901 & 11,056 & 12,783 \\
\hline $\operatorname{Age}^{(6)}$ & 45 & 7 & 45 & 45 & 49 & 41 \\
\hline Absolute risk aversion $\left(10^{5}\right)^{(2)}$ & 29 & 14 & 27 & 31 & 29 & 30 \\
\hline Discrete variables & $\%$ of the sam! & & & & & \\
\hline Risky Asset Holdings ${ }^{(7)}$ & $33 \%$ & & $27 \%$ & $38 \%$ & $34 \%$ & $33 \%$ \\
\hline Inheritance & $19 \%$ & & $19 \%$ & $20 \%$ & $22 \%$ & $17 \%$ \\
\hline $\begin{array}{l}\text { Inter vivos transfers and gifts } \\
\text { received }\end{array}$ & $52 \%$ & & $52 \%$ & $52 \%$ & $50 \%$ & $54 \%$ \\
\hline Paris & $16 \%$ & & $16 \%$ & $16 \%$ & $14 \%$ & $17 \%$ \\
\hline Parents own risky assets & $24 \%$ & & $22 \%$ & $25 \%$ & $22 \%$ & $26 \%$ \\
\hline Internet & $33 \%$ & & $31 \%$ & $34 \%$ & $31 \%$ & $35 \%$ \\
\hline Women & $15 \%$ & & $15 \%$ & $15 \%$ & $17 \%$ & $14 \%$ \\
\hline Homeownership & $67 \%$ & & $67 \%$ & $67 \%$ & $73 \%$ & $61 \%$ \\
\hline Child (if $\mathrm{n}^{\circ}$ of children $>0$ ) & $44 \%$ & & $47 \%$ & $43 \%$ & $23 \%$ & $65 \%$ \\
\hline Liquidity constraints ${ }^{(2)}$ & $20 \%$ & & $20 \%$ & $20 \%$ & $15 \%$ & $24 \%$ \\
\hline She has been unemployed & $52 \%$ & & $52 \%$ & $52 \%$ & $43 \%$ & $62 \%$ \\
\hline Working in a big firm & $16 \%$ & & $14 \%$ & $17 \%$ & $16 \%$ & $17 \%$ \\
\hline \multicolumn{7}{|l|}{ Relative risk aversion (CRRA): } \\
\hline Non respondents & $7 \%$ & & $8 \%$ & $7 \%$ & $12 \%$ & $2 \%$ \\
\hline CRRA $<1$ & $8 \%$ & & $22 \%$ & $20 \%$ & $11 \%$ & $4 \%$ \\
\hline $1 \leq \mathrm{CRRA}<2$ & $20 \%$ & & $24 \%$ & $30 \%$ & $21 \%$ & $19 \%$ \\
\hline $2 \leq \mathrm{CRRA}<3.76$ & $28 \%$ & & $37 \%$ & $37 \%$ & $19 \%$ & $37 \%$ \\
\hline $\mathrm{CRRA} \geq 3.76$ & $37 \%$ & & $10 \%$ & $6 \%$ & $36 \%$ & $38 \%$ \\
\hline \multicolumn{7}{|l|}{$\begin{array}{l}\text { Correlation between income } \\
\text { risk and stock market risk: }{ }^{(2)}\end{array}$} \\
\hline$\rho>0$ (non-positive correlation) & $34 \%$ & & & & $32 \%$ & $35 \%$ \\
\hline$\rho<0$ (negative correlation) & $62 \%$ & & & & $61 \%$ & $62 \%$ \\
\hline Non-respondents & $4 \%$ & & & & $6 \%$ & $3 \%$ \\
\hline \multicolumn{7}{|l|}{ Discrete income risk variable } \\
\hline Non-irregular income & $77 \%$ & & $74 \%$ & $78 \%$ & $79 \%$ & $74 \%$ \\
\hline Irregular income & $20 \%$ & & $20 \%$ & $20 \%$ & $16 \%$ & $23 \%$ \\
\hline Non-respondents & $4 \%$ & & $7 \%$ & $2 \%$ & $5 \%$ & $3 \%$ \\
\hline \multicolumn{7}{|l|}{$\begin{array}{l}\text { Education of the head of the } \\
\text { household: }\end{array}$} \\
\hline No diploma or primary level & $6 \%$ & & $7 \%$ & $5 \%$ & $3 \%$ & $9 \%$ \\
\hline Primary or secondary level & $41 \%$ & & $45 \%$ & $39 \%$ & $43 \%$ & $40 \%$ \\
\hline Baccalaureate & $21 \%$ & & $19 \%$ & $21 \%$ & $19 \%$ & $22 \%$ \\
\hline Graduate studies & $25 \%$ & & $22 \%$ & $27 \%$ & $27 \%$ & $23 \%$ \\
\hline Post-graduate studies & $7 \%$ & & $7 \%$ & $7 \%$ & $8 \%$ & $6 \%$ \\
\hline Number of households & 2,406 & & 923 & 1,483 & 1,203 & 1,203 \\
\hline
\end{tabular}

Source: 'DELTA - TNS 2002'. Absolute risk aversion takes value 0 for risk neutrals and 40 for the most risk averse.

(1) The 54 households who are risk lovers (with negative absolute risk aversion) are dropped off the sample.

(2) See the appendix for further details about the construction of the variables.

(3) Financial wealth: household's total financial wealth in French francs.

(4) Income: household's annual income in French francs.

(5) Income risk: standard deviation of expected income per unit of income estimated from "Patrimoine 98" using household characteristics of 'DELTA - TNS 2002'. Income is in French francs.

(6) Age: age of the head of the household.

(7) Risky asset holdings: the household holds equities either directly (includes national and foreign stocks) or indirectly (through mutual funds).

(8) Low-income risk and High-income risk households are those, respectively, below and above the median of the distribution of relative income risk $\left(\sigma^{2} / \mathrm{y}\right)$. 
Table 3: Heteroscedastic Probit Estimation

\begin{tabular}{|c|c|c|c|}
\hline $\begin{array}{l}\text { Direct and Indirect Risky Asset } \\
\text { Holdings }\end{array}$ & $\begin{array}{c}\text { Discrete } \\
\text { Income Risk }\end{array}$ & $\begin{array}{l}\text { Instrumented } \\
\text { Income Risk }\end{array}$ & $\begin{array}{c}\text { Interacting } \\
\text { Instrumented } \\
\text { Income Risk and } \\
\text { Correlation } \\
\end{array}$ \\
\hline Variables & (1) & (2) & (3) \\
\hline \multirow{3}{*}{$\begin{array}{l}\text { Financial wealth }(10 \mathrm{E}-6)^{(2)} \\
\text { Financial wealth squared }(10 \mathrm{E}-12) \\
\text { Income }(10 \mathrm{E}-6)^{(3)}\end{array}$} & $6.046(0.855)$ & $6.098(0.852)$ & $6.142(0.852)$ \\
\hline & $-1.788(1.379)$ & $-1.798(1.409)$ & $-1.846(1.424)$ \\
\hline & $0.85(0.462)$ & $0.865(0.474)$ & $0.852(0.474)$ \\
\hline Income squared (10E-12) & $-0.288(0.246)$ & $-0.284(0.252)$ & $-0.285(0.254)$ \\
\hline $\begin{array}{l}\text { Discrete income risk dummy } \\
\text { Neg Corr between income risk and }\end{array}$ & $0.155(0.092)$ & - & - \\
\hline $\begin{array}{l}\text { stock market risk } \\
\text { Income risk }^{(5)}\end{array}$ & $\begin{array}{c}0.323(0.074) \\
-\end{array}$ & $\begin{array}{l}0.324(0.074) \\
0.649(1.243)\end{array}$ & - \\
\hline \multicolumn{4}{|l|}{ Income risk effect: } \\
\hline For individuals with $\rho \geq 0$ & - & - & $-2.963(1.547)$ \\
\hline For individuals with $\rho<0$ & - & - & $1.519(1.179)$ \\
\hline Working in a big firm & $0.591(0.091)$ & $0.578(0.091)$ & $0.58(0.091)$ \\
\hline $\operatorname{Age}^{(7)}$ & $0.121(0.049)$ & $0.124(0.049)$ & $0.123(0.049)$ \\
\hline Age squared (10E-3) & $-1.319(0.513)$ & $-1.343(0.517)$ & $-1.33(0.513)$ \\
\hline Inheritance & $0.155(0.089)$ & $0.163(0.089)$ & $0.167(0.089)$ \\
\hline Inter vivos transfers & $0.111(0.072)$ & $0.112(0.072)$ & $0.111(0.073)$ \\
\hline Paris & $0.341(0.099)$ & $0.332(0.099)$ & $0.34(0.099)$ \\
\hline Parents own risky assets & $0.498(0.084)$ & $0.491(0.084)$ & $0.496(0.084)$ \\
\hline $\begin{array}{l}\text { Whether the individual answers the risk } \\
\text { aversion question }\end{array}$ & $0.873(0.176)$ & $0.859(0.176)$ & $0.871(0.176)$ \\
\hline Absolute risk aversion & $-0.02(0.004)$ & $-0.019(0.004)$ & $-0.019(0.004)$ \\
\hline Internet & $0.308(0.075)$ & $0.31(0.075)$ & $0.312(0.075)$ \\
\hline Woman & $-0.292(0.113)$ & $-0.281(0.114)$ & $-0.279(0.114)$ \\
\hline House ownership & $0.157(0.083)$ & $0.153(0.083)$ & $0.154(0.083)$ \\
\hline Child (if children >0) & $-0.087(0.084)$ & $-0.09(0.085)$ & $-0.08(0.085)$ \\
\hline Liquidity constraints & $-0.334(0.099)$ & $-0.31(0.098)$ & $-0.316(0.098)$ \\
\hline Constant & $-4.682(1.15)$ & $-4.793(1.168)$ & $-4.524(1.159)$ \\
\hline Sigma (financial wealth) & $1.652(0.324)$ & $1.678(0.328)$ & $1.692(0.327)$ \\
\hline LR test of sigma $=0\left[\right.$ distributed $\left.\chi^{2}(1)\right]$ & 51.943 & 53.851 & 54.827 \\
\hline Number of observations & 2,406 & 2,406 & 2,406 \\
\hline
\end{tabular}

Source: 'DELTA - TNS 2002' survey and own calculations. Standard errors are in brackets. Absolute risk aversion takes value 0 for risk neutrals and 40 for the most risk averse.

(1) Households who are risk lovers (with $\mathrm{Zi}>5000$ ) are dropped off the sample (54).

(2) Household's total financial wealth in French francs.

(3) Household's annual income in French francs.

(4) The parameter $\rho$ tries to measure the correlation between income risk and stock market risk. A different coefficient for income risk is computed depending on the sign of the correlation. See Appendix for details.

(5) Income risk: standard deviation of expected income per unit of income estimated from "Patrimoine 98" using household characteristics of 'DELTA - TNS 2002'. See the appendix and table A1 for details. Income in French francs.

(6) Age: age of the head of the household. 


\begin{tabular}{|c|c|c|c|c|}
\hline Variables & $\begin{array}{c}\text { Est. (s. e.) } \\
(1) \\
\end{array}$ & $\begin{array}{c}\text { Variable mean } \\
\text { (DELTA-TNS } \\
\text { 2002) } \\
(2) \\
\end{array}$ & $\begin{array}{c}\text { Variable mean } \\
\text { (Patrimoine 98) } \\
\text { Ages 35-55 } \\
(3) \\
\end{array}$ & $\begin{array}{c}\text { Variable mean } \\
\text { (Patrimoine 98) } \\
\text { Whole sample } \\
(4) \\
\end{array}$ \\
\hline Income & $0.044(0.003)$ & 201,847 & 201,860 & 169,611 \\
\hline Age & $-389(109)$ & 45 & 45 & 50 \\
\hline Age squared & $2.365(1.084)$ & 2,093 & 2,064 & 2,733 \\
\hline Health problems & $3,004(1,421)$ & $5 \%$ & $3 \%$ & $3 \%$ \\
\hline Child (if $\mathrm{n}^{\circ}$ of children $>0$ ) & $1,623(813)$ & $44 \%$ & $85 \%$ & $76 \%$ \\
\hline Post-graduate studies & $1,348(906)$ & $7 \%$ & $12 \%$ & $11 \%$ \\
\hline \multicolumn{5}{|l|}{ Occupational status: } \\
\hline Trader or craftsman & $-644(1,761)$ & $5 \%$ & $8 \%$ & $5 \%$ \\
\hline Profession & $-737(1,642)$ & $15 \%$ & $22 \%$ & $15 \%$ \\
\hline Foreman & $-1,493(1,559)$ & $27 \%$ & $23 \%$ & $15 \%$ \\
\hline Employee & $-3,059(1,590)$ & $16 \%$ & $16 \%$ & $12 \%$ \\
\hline Blue collar worker & $-3,070(1,553)$ & $27 \%$ & $21 \%$ & $15 \%$ \\
\hline Retired & $-4,044(1,687)$ & $6 \%$ & $1 \%$ & $29 \%$ \\
\hline Inactive & $-4,737(1,802)$ & $3 \%$ & $3 \%$ & $6 \%$ \\
\hline \multicolumn{5}{|l|}{ Personal Status: } \\
\hline Cohabitation & $2,331(1,031)$ & $10 \%$ & $8 \%$ & $9 \%$ \\
\hline Single & $-1,418(995)$ & $16 \%$ & $16 \%$ & $23 \%$ \\
\hline Divorced & $-2,099(926)$ & $10 \%$ & $13 \%$ & $9 \%$ \\
\hline Widow & $441(948)$ & $2 \%$ & $3 \%$ & $10 \%$ \\
\hline \multicolumn{5}{|c|}{$\begin{array}{l}\text { Constant relative risk aversion } \\
\text { (CRRA): }\end{array}$} \\
\hline No answer & $-791(780)$ & $7 \%$ & $11 \%$ & $14 \%$ \\
\hline $1 \leq \mathrm{CRRA}<2$ & $1,895(583)$ & $28 \%$ & $36 \%$ & $34 \%$ \\
\hline $2 \leq \mathrm{CRRA}<3.76$ & $3,263(869)$ & $21 \%$ & $11 \%$ & $10 \%$ \\
\hline $\mathrm{CRRA} \geq 3.76$ & $2,423(1,123)$ & $8 \%$ & $6 \%$ & $5 \%$ \\
\hline \multicolumn{5}{|l|}{ Portfolio risk preference: } \\
\hline Very small & $-307(1,369)$ & $47 \%$ & $59 \%$ & $63 \%$ \\
\hline Small & $88(1,440)$ & $42 \%$ & $34 \%$ & $29 \%$ \\
\hline High & $3,665(1,791)$ & $4 \%$ & $5 \%$ & $4 \%$ \\
\hline \multicolumn{5}{|c|}{$\begin{array}{l}\text { Probability to be unemployed in } \\
5 \text { years: }\end{array}$} \\
\hline Very small & $-930(961)$ & $45 \%$ & $43 \%$ & $35 \%$ \\
\hline Small & $764(951)$ & $26 \%$ & $36 \%$ & $36 \%$ \\
\hline High & $1,937(1,095)$ & $6 \%$ & $9 \%$ & $13 \%$ \\
\hline Very high & $1,637(1,190)$ & $3 \%$ & $6 \%$ & $8 \%$ \\
\hline \multicolumn{5}{|l|}{ Region: } \\
\hline Paris Ile-de-France & $-1,712(874)$ & $18 \%$ & $15 \%$ & $17 \%$ \\
\hline Nord & $-835(1,157)$ & $7 \%$ & $17 \%$ & $7 \%$ \\
\hline East & $-961(927)$ & $10 \%$ & $6 \%$ & $13 \%$ \\
\hline West & $-1,540(924)$ & $14 \%$ & $13 \%$ & $14 \%$ \\
\hline Sud-West & $-13(1,026)$ & $11 \%$ & $13 \%$ & $9 \%$ \\
\hline Sud-East & $-2,010(959)$ & $11 \%$ & $9 \%$ & $12 \%$ \\
\hline Mediterranean & $-1,632(923)$ & $12 \%$ & $13 \%$ & $14 \%$ \\
\hline Constant & $16,137(3,506)$ & & & \\
\hline Number of obs. & 2,460 & 2,460 & 1,043 & 2,390 \\
\hline Adj. R-sq & 0.2603 & & & \\
\hline $\mathrm{F}(35,2355)$ & 25.03 & & & \\
\hline Prob. > F & 0.0001 & & & \\
\hline
\end{tabular}

Source: 'Patrimoine 98' INSEE survey. Standard errors are in brackets.

Reference values are: for occupational status "Agriculture", for familiar status "Married", CRRA $\geq 3.76$, for savings preferences and probability to be unemployed "Very high" and for region "Paris". 
Table A2: Absolute Risk Aversion Estimation ${ }^{(1)}$

Dependent variable

Ln Absolute risk aversion

Ln financial wealth

$-0.021(0.010)$

Paris

$-0.007(0.042)$

Women

$0.086(0.042)$

Age

$0.002(0.002)$

Child (if children $>0$ )

$0.076(0.032)$

She has been unemployed

$-0.005(0.028)$

Parents own risky assets

$-0.044(0.035)$

Education level of head of the household:

Primary or secondary level

$-0.094(0.044)$

Baccalaureate

$-0.122(0.052)$

Graduate studies

$-0.153(0.054)$

Post-graduate studies

$-0.280(0.088)$

Constant

$3.699(0.156)$

Adj. R-squared $=0.0148 \quad$ No. of obs. $=2088$

$\mathrm{F}(10,2077)=3.84 \quad$ Prob $>\mathrm{F}=0.0000$

Source: 'DELTA - TNS 2002' survey and own calculations. Standard errors are in brackets. Absolute risk aversion takes value 0 for risk neutrals and 40 for the most risk averse.

(1) Risk lovers are included in the OLS regression. 2088 out of 2460 answered the absolute risk aversion question.

Note: The normality test of residuals has been rejected. Therefore bootstrapped standard errors are reported in brackets (based on 200 replications). No diploma is used as the reference group. 